\title{
The Political Context of John Mulgan's Greek Wartime Life and Death ${ }^{1}$
}

\author{
MARTYN BROWN
}

\section{Introduction}

In late March 1965, distinguished New Zealand diplomat Joseph (J.V.) Wilson offered Paul Day, who was then writing a biography of John Mulgan, some materials that needed 'circumspect handling both because of their content and because of the circumstances in which they were written'. The items in question were letters sent to the Wellington-based diplomat Wilson in response to a request he had made to the soldier Mulgan in January 1945 for an assessment of the political situation in liberated Greece. The two had known each before the war, when they were part of the New Zealand delegation to the League of Nations. Mulgan's letters were typed just a few days before his death during the night of 25/26 April in Cairo. Wilson's caution - he wanted any extracts to be confined to those 'for the purposes of your biography'2 - shows his desire to avoid engaging with the political nature of the letters. He was also respecting Mulgan's request to limit circulation because, as Mulgan wrote to Wilson in 1945, 'as an army officer I'm not officially free to write or express my views without censorship'. ${ }^{3}$ Day, for his part, reversed an earlier request for making copies, in deference to Wilson's 'reservations about reproduction'. He also thought 'it most unlikely that I shall wish to quote from these documents', but would rely on other sources to build a picture of the 'Greek political scene'. The biographer thought, 'The account of the Greek political scene is interesting, though generalized. ${ }^{4}$ This short exchange provides a place of embarkation for this paper.

John Mulgan's death has been attributed in the literature to his disillusionment following German reprisals against Greek civilians, which his sabotage work provoked, and the effects of his compensation work in Athens following liberation: 'Overwrought, he killed himself before he was thirtyfive'. ${ }^{5}$ This study shows Mulgan's death deserves reconsideration, because people at the time sought explanations other than the official verdict of suicide. As such, this paper offers both a wider perspective on John Mulgan 
the individual, and a revisionist treatment of New Zealand diplomatic war history. For historians of Anglo-Greek wartime relations, the use of New Zealand archives and manuscripts shows how seemingly peripheral sources can contribute to a much-discussed area - one which has not, up to now, included New Zealand.

\section{Historical background}

Mulgan arrived in enemy-occupied Greece on 12 September 1943. He was a member of Britain's Special Operations Executive (SOE), a special forces organization which operated in all war theatres. Although SOE Greece had a number of New Zealanders seconded from the New Zealand forces in its ranks already, Mulgan was in fact in the British army when he volunteered to join the organization. His first period in Greece ended in November 1944, shortly after liberation. His time was spent in sabotage missions (especially against trains). Like his SOE colleagues in Greece this involved working with the local partisans. However, he did not face the same political complexities that most of them did because he only had to deal with one of the competing resistance groups in his area. The highly charged political dynamics of wartime Greece had led to divisions within the British politico-military establishment over their Greek policy. If Mulgan had arrived in Greece just a few months earlier his commanding officer would have been Brigadier Eddie Myers and not Chris Woodhouse (the British SOE personality often mentioned or cited in biographies of Mulgan). Myers had been removed from his command because he clashed with the British Foreign Office over how the volatile situation in occupied Greece should be handled. Mulgan shared something with Myers in that both were critical of British policies. Mulgan however, kept his views largely confined to himself or personal correspondents; Myers went all the way up to Winston Churchill with his. Myers never returned to occupied Greece.

Following liberation, Mulgan went to Cairo but accepted an administration assignment that required him to return to Athens in January 1945. While the literature has stressed that his work in Athens concerned compensation activities, this study shows Mulgan had an involvement in the still festering politics of wartime Greece during this period, as well as looking out for British interests. In late April he again travelled to the Egyptian capital, where he was found dead on 26 April, just a few days before his requested transfer to the New Zealand Second Division was to be actioned. It was also shortly after he wrote to J.V. Wilson. These are the basic facts regarding Mulgan's service with SOE in Greece. The following is a brief contextual overview of the historical background to wartime Greece and the period immediately preceding it. 


\section{Pre-War Greece and the Greek government in exile}

On 4 August 1936, General Ioannis Metaxas used the perceived threat of a Communist revolution, and the support of the Greek monarch, King George II, to establish a Greek dictatorship. The dictatorship had the trappings of National Socialist ideology. The confiscation and public burning of books by Greek and foreign authors such as George Bernard Shaw, Goethe and Freud took place, as well as censorship of Greek classics. ${ }^{6}$ State Security was managed by Sub-Minister Constantine Maniadakis. His expertise in social control through the use of torture and other means gained him a reputation for grim efficiency. Just how widely the regime cast its repressive net can be judged by the extensive use of forced public Declarations of Repentance. The declarations were obtained from alleged enemies of the state and then published. In his 2004 work Greek historian Andre Gerolymatos has noted how one Metaxist minister stated the number of declarations reached 57,000 - four times the membership of the pre-war Greek Communist Party. This 'must be attributed to the excessive zeal of the police, who often seized individuals merely suspected of communist sympathies'.? Maniadakis' originality led him to establish a completely bogus Communist Party structure in parallel to the genuine one. The resulting confusion weakened the communists but the experience they gained in surviving placed them in a prime position to grow and influence the wartime resistance.

As the Germans advanced triumphantly through mainland Greece in April 1941, the Greek government, including the new Greek premier Emmanuel Tsouderos (Metaxas died in January 1941 and his successor committed suicide shortly after German victory was assured), and King George II, fled to Crete. Included in their ranks were Maniadakis and other Metaxist ministers. Maniadakis continued his state responsibilities on Crete - the battle for which holds a prominent place in New Zealand history and popular memory. Opposition from the local people against Maniadakis and the still-enforced Metaxist measures led to protests to the Greek king and his administration. Such pressure resulted in several ministers (including Maniadakis) being removed from the island. ${ }^{8}$ Following the loss of the Greek mainland and Crete to the invading German army, the government and king operated out of London and Cairo and enjoyed the support of the British government, especially Winston Churchill. To one degree or other, the Metaxists remained in the government-in-exile up until May 1942, when they 'were removed from key jobs'. ${ }^{9}$ But Metaxist sympathizers remained inside the Greek administration-in-exile and within the armed forces they raised in the Middle East. For example, as late as August 1944, American intelligence reported that the main unit in the Greek government armed forces was singing Metaxist songs as it arrived in Italy. ${ }^{10}$ 
The armed forces raised by the Greek establishment in the Middle East were wracked by internal political division. Groups of soldiers with various and often conflicting ideological inclinations - for example, Republicans, Monarchists, Communists and Metaxists - vied for influence within the forces. The leftist Anti-Fascist Military Organization (ASO) was the largest faction. It challenged the continuation of King George and his administration. Their views were expressed through agitation, the most spectacular being the mutinies in the Greek armed forces of the Middle East in early 1943 and 1944. The mutinies led to the fall of two Greek premiers and to several reorganizations of the government. When Mulgan arrived in Greece during late 1943, Emmanuel Tsouderos was still Greek premier in the governmentin-exile. He resigned during the mutiny of April 1944 and was followed in a matter of days by his successor, Sofoklis Venizelos. George Papandreou then became premier and was still in power at the time of Greek liberation later that year. The period of liberation brought the British Army and the Greek government-in-exile into direct contact with the anti-Axis resistance forces of the EAM (National Liberation Front) and its military arm ELAS (National Liberation Army) in Greece. Open warfare erupted between them in December 1944. It lasted into the new year, when Mulgan returned to Athens to undertake his final SOE work.

\section{Inside wartime Greece}

The failed Greek campaign of 1941 led to the trauma of Axis (Italian, German and Bulgarian) occupation of the country for more than three years. Within Greece, various resistance forces emerged. Each had its own political alignment. The largest group would challenge the Greek monarch, his government-in-exile, and thereby the major power that sponsored them, Great Britain. This was the leftist EAM and its military arm ELAS. However, the pragmatic requirements of fighting the Axis enemy meant that the British provided arms and supplies to any partisan movement which would combat the Axis. Defeating the enemy was the immediate objective. The longer-term aim was ensuring British influence in Greece. While the former meant tolerating EAM/ELAS, the latter entailed minimizing their political influence during the occupation and also at the time of liberation. By the end of his first few months in occupied Greece, Chris Woodhouse, Mulgan's commanding officer in Greece, concluded that the rank and file of EAM/ELAS were not aware that the Greek Communist Party secretly controlled their organization.

In terms of political preferences, Britain supported the right wing EDES (National Republican Greek League). Despite its name, which seemingly contradicts acceptance of the monarch, EDES was persuaded to change its original social reform agenda through British promises of support. Chris 
Woodhouse would also write, after the war, that its leader, Napoleon Zervas, 'had only been induced to take the field by strong pressure, amounting almost to blackmail'." Despite British attempts at limiting their influence, EAM/ ELAS successfully liquidated a number of smaller resistance groups as it strove to dominate the resistance movement inside occupied Greece. The most notable of these groups was National and Social Liberation (EKKA). Mulgan would play an unwitting part in that episode.

Within Greece then, it was the British Liaison Officers (BLOs) like Mulgan who engaged at the coal face with the various political forces. This involved both political and military responsibilities.

\section{John Mulgan and Anglo-Greek wartime historiography}

John Mulgan figures as an incidental character in political analyses of Anglo-Greek relations and in the wider international relations publication record. This is a realm not examined to any meaningful extent by New Zealand historians, who have placed New Zealand on the extreme boundary of the interplay between the exigencies of war, conflicting internal Greek ideological forces, and the strategic interests of the major powers - Britain, the Soviet Union and the United States. Mulgan's role does not attract any notable discussion, although his views on the ever-diminishing effectiveness of the Greek andartes (partisan) forces in Report on Experience ${ }^{12}$ are cited by the Greek history scholar Mark Mazower in Inside Hitler's Greece. ${ }^{13}$ Similarly, M.R.D. Foot, one of the early SOE historians, also cites Report on Experience and concludes that Mulgan was 'perceptive' and 'a New Zealand scholar of broad sympathies and a reflective mind, who did marvels as a train saboteur, and was appalled at the way that two men who were hard-bitten enough [that is, EAM/ELAS functionaries] could dominate the life of a hill village'. ${ }^{14}$ In an examination of the relationship between the British Military Mission and their American counterparts, Richard Clogg, the historian appointed to write an official history of SOE in Greece, quotes a report from Mulgan, where he states a preference for working with American over American-Greek (that is, Americans with Greek heritage) personnel. Clogg also describes how British attempts at blunting American criticism of their handling of the Greek situation led to an American intelligence research analyst being sent to Mulgan's area so that he could see the effective working relationship Mulgan had established there with ELAS. ${ }^{15}$ That same relationship is described in the memoirs of Nicolas Hammond, an SOE colleague of Mulgan's, as fitting in with the ELAS strategy to gain political leverage with the British: 'It was a regular gambit of ELAS to have one such model area'. Hammond pointed out that Mulgan's success was known at senior levels: 'At this time, ELAS GHQ always pointed to Mulgan's area 
as the one in which ELAS co-operation was freely given, because Mulgan treated ELAS properly'. ${ }^{16}$

Unfortunately, Stefanos Sarafis, the senior ELAS commander at the ELAS GHQ that Hammond refers to, only fleetingly mentions Mulgan in his published recollections. And then only as someone who assisted him on a flight from Greece. A footnote mistakenly calls Mulgan an Australian but correctly identifies him as the author of Report on Experience. ${ }^{17}$ There is no discussion of the man nor of the views he put forward in that work.

Mulgan's military effectiveness and positive working relationship with ELAS may have caught the attention of political actors during the occupation and subsequently historians, but ELAS was not the only resistance group he encountered. One recent study has highlighted how, even in his seemingly exceptional circumstances, Greek internecine terror touched him. The study is by Argyrios Mamarelis, who has used Public Records Office archives at Kew to dispel some of the many popular stories concerning the death of independent partisan leader Colonel Dimitrios Psarros and the massacre of his men.

Psarros headed the National and Social Liberation (EKKA) resistance group. In April 1944, Psarros and partisans of EKKA's military arm were disarmed by ELAS and subsequently 'murdered under mysterious circumstances'. ${ }^{18}$ On two previous occasions, ELAS had disarmed the same group, but with no subsequent killing. Thus, British Liaison Officers, including Mulgan, thought little of the signs that a third occasion was about to occur. Mulgan sent a telegram to SOE HQ in Cairo: 'The EKKA/ELAS trouble is apparently not serious. I expect it to blow over'. Indeed, Mulgan's more senior colleagues in Greece thought the trouble of maintaining EKKA as a minor separate body was not worth the effort. ${ }^{19}$ Through his dismissal of the tension, the New Zealander had unwittingly contributed to the massacre. His telegram, together with other communications involving Mulgan, is used by Mamarelis to argue that there was no British conspiracy concerning EKKA. However, as discussed later, the fate of EKKA would revisit John Mulgan in Athens during early 1945 when he was managing recompense to Greeks who had assisted SOE.

Mulgan, then, receives most attention in the extant Anglo-Greek literature because of his critical views on the partisan movement, his individual success and its use by the competing political players in Greece. Other than this, he attracts brief mention - probably because he simply was not high enough in the decision-making circles to participate in the strategic policies and actions as colleagues like Nicholas Hammond and Chris Woodhouse were. It is New Zealand biographers who introduce an international relations dimension to the discussion. They do this by quoting Mulgan and also by making brief mention of a communication he had with a government that was not one of 
the major powers involved in Greece - Peter Fraser's New Zealand wartime administration. Mulgan's critical comments on British foreign policy have been ignored in the mainstream Anglo-Greek literature, while the connection with Fraser's administration has never been fully explored. Similarly, the nature of Mulgan's compensation work in Athens has been treated solely as a debilitating encounter with human misery. This view has ignored the political legacy that accompanied the experience, as well as Mulgan's involvement in the murky and charged atmosphere of Athens.

\section{John Mulgan - New Zealand biographical material}

Biographical studies on John Mulgan have focused primarily on the short but varied course of his entire life. As a natural consequence, his time with SOE Greece receives a restricted analysis. The one item in the publication record that focuses entirely on Mulgan's Greek-related experiences is Dean Parker's play, Greek Fire..$^{20}$ Although the play refers to the political background of the partisan warfare in Greece and intelligence operatives in Cairo, it does not provide specific details about the national actors and the international relations context and events of the day. New Zealand biographers of Mulgan, to varying degrees, discuss his dislike of the Greek communists, his revulsion at, and feeling of responsibility for the Axis reprisals, his often-applauded sabotage work and his criticism of British foreign policy. ${ }^{21}$ A paragraph in Vincent O'Sullivan's biography shows that, at least in April 1945, after the Germans had left Greece and Britain had returned with its Greek émigré-sponsored administration, Mulgan had some sort of link to the New Zealand government (in the form of J.V. Wilson, a diplomat): 'Wilson asked for Mulgan's views on the Greek situation'. The latter wrote a report that O'Sullivan estimates to be 'more than 4,000 words in reply'. Mulgan's views show that he was an independent thinker about Greece: 'His concluding views were cogent and unfashionable - Britain should get out, and an international military government preside until democratic processes could work'. ${ }^{22}$ James McNeish refers to the same communication but simply notes it as one of the letters written just before Mulgan's death in Cairo and does not identify Mulgan's correspondent. ${ }^{23}$ The background and motivation for the report are not discussed by either biographer. What makes the communication more intriguing is the sparseness in the literature over New Zealand's stance of neutrality toward Anglo-Greek relations. This stance is briefly explained in F.L.W. Wood's official history as, '. . an unwillingness to take sides in Greek politics as well as a desire to get the NZEF home as soon as fighting had ceased'. ${ }^{24}$ The resolve to bring the NZEF home ran counter to a British request for New Zealand garrison troops after the end of hostilities and for a small detachment of the Dominion's troops to enter Athens with the returning British. These requests were received and turned 
down before Wellington contacted Mulgan. Thus it appears that there was continued deliberation in Wellington over the Greek question.

\section{4 - Time of liberation and the uneasy Anglo-Greek alliance collapse}

In October 1944, British troops arrived in Greece on the heels of the Germans, who had vacated the country. Such a development had long been anticipated by the Allies and the Germans, as the advancing Soviet armies to the north would have trapped the Nazi forces in the Balkan peninsular. Churchill's fear of a coup d'état by EAM/ELAS had led to the planning of Operation MANNA to quickly establish the Greek government in exile in Athens, with the support of British and loyal Greek troops, in the vacuum left by the Germans. After several tense months, fighting erupted between ELAS and the allied British, EDES, and exiled Greek government forces. EDES were quickly overwhelmed by ELAS and were evacuated to the island of Corfu by British warships. The spark that ignited the powder keg was the Athens police opening fire on an EAM demonstration in Constitution Square. On 5 December, the New Zealand Herald reported: 'For 25 minutes Greek police poured a withering fire from machine guns, tommy-guns and mortars and light anti-tank guns into the ranks of unarmed demonstrators of the EAM (Left Wing party)'. ${ }^{25}$ Initial fighting between the Athens police and ELAS soon escalated. The British joined in as ELAS got the upper hand. The New Zealand press reports were dominated by accounts of use of British advanced weaponry and airpower in the city of Athens, the incident in Constitution Square and the return of a monarch and government with questionable credibility to govern in a democracy. A small piece on ELAS taking hostages and carrying out executions on 12 December was an early indication of the atrocities associated with their actions. ${ }^{26}$

Britain and her Greek allies eventually prevailed, and ELAS was forced out of the city. On 12 February 1945, the Varkiza Agreement was signed by the parties. The terms of the Agreement included the lifting of martial law, amnesty, purging of the civil service and security services, demobilization of partisans and the establishment of a national army and restoration of political liberties. However, ELAS still controlled a major part of rural Greece. Before the Agreement was signed, right-wing paramilitary groups were active and seemingly supported by the victors. On 15 January, The Times reported how the collaborationist ' $\mathrm{X}$ ' organization joined with EDES and other groups in a mass demonstration (the article did not mention the organization's former association with the occupiers). The demonstration included chanting in support of the British commander, General Scobie, and ubiquitous portraits of the Greek King. ${ }^{27}$ Chris Woodhouse would write in one of his histories of Greece that $\mathrm{X}$ had no link to the British during the occupation, although 
its leader, George Grivas, like many other officers, had been approached by British agents to take up resistance against the Axis (that is, to provide a counter to ELAS power). Woodhouse has written about Grivas and his group during the early post-liberation period thus: 'a gang of thugs . . . to fight the similar gangs of Communists in the streets of Athens' ${ }^{28}$ The $\mathrm{X}$ organization would extend its killing to a wide range of political opponents in the future. In hindsight, the Varkiza Agreement was only a temporary and partial respite in the political turmoil of Greece. ${ }^{29}$ The temporary upheaval that started in late December brought repercussions to the government of Peter Fraser. A large number of New Zealand troops had fought in Greece and/or been assisted by the local population in a most compassionate way. Such a direct interaction made for a strong popular response to events in December 1944.

\section{Wellington government and New Zealand popular protest against British actions in Athens during December 1944}

During December 1944, the New Zealand government received messages of protest from throughout the country, decrying what was often called 'British intervention' in Greece. Most were from trade unions and Labour Party branches. Unsurprisingly, the Communist Party of New Zealand also registered its objections. ${ }^{30}$ The press carried stories about the protests ${ }^{31}$ as well as reporting a petition signed by 248 soldiers at Burnham Camp that was sent to Peter Fraser. ${ }^{32}$ Fraser ruled out the possibility of Dominion troops entering the battle raging in Athens, and issued a statement to the effect that: 'There are no New Zealand troops in Greece and no likelihood whatever of New Zealand troops being sent to Greece'. ${ }^{33}$ This was a decision made months previously and noted in the extant history. Under enormous pressure, Fraser was making public a previously confidential policy decision.

The domestic protest, together with Churchill's response to a question in the House of Commons on 14 December, prompted Peter Fraser to send a telegram of protest to London. Churchill's statement was clearly the predominant trigger. The British Prime Minister had stated that the British dominions had been kept informed of high policy through a 'continued succession of telegrams which are sent from this country' but that certain circumstances require swift and forced 'executive measures' which precluded extensive consultation. Churchill ended thus: 'I could rightfully say that we have received from the Dominion Governments no indications that they dissent from the action we have been compelled to take'. ${ }^{34}$ Churchill was referring to the standard practice of distributing information through British diplomatic channels. The intimation was that Britain had the full support of the commonwealth - including New Zealand. 
On 20 December, Fraser sent his telegram of protest to London. He told the Secretary of State for Dominion Affairs that, while he had been trying to contain criticism concerning British actions, Churchill's statement made it necessary for him to communicate a formal position. Besides reiterating criticisms of the Greek monarch he had apparently made at the Prime Ministers' Meeting in early 1944, he requested a clear statement as to the outcomes London was trying to achieve in Greece. He balanced this request with a repudiation of those who would 'impose their will by force of arms' [probably a reference to EAM/ELAS]. The traditional practice of publicly maintaining commonwealth solidarity while permitting private disagreement explains some of Fraser's telegram as well as his behaviour in the New Zealand parliament. In his communication of 20 December, Fraser clearly showed he was not willing to publicly break with Britain, nor was he going to permit the Greek crisis to be discussed in the country's pre-eminent political forum. He told London that: 'We have endeavoured to prevent any considerable volume of hostile criticism' and that he had prevented questions being raised about Greece in the New Zealand Parliament. Fraser highlighted the presence of the trade union movement and Labour Party members in the protest. He did not mention the petition from the soldiers at Burnham. This could possibly have been too embarrassing for him to mention - to tell Churchill about popular civilian protest was one thing, to acknowledge protest emanating from the troops was another. Fraser then attributed the cause of the protest to British support for the Greek monarchy. Indeed, besides Greece, he mentioned Yugoslavia and Italy: 'the fact is plain that the majority of the people of their countries do not want them [that is, the former monarchs] back to reign over them'. Fraser concluded his telegram by asking for a clear assurance that Britain was not undertaking to restore monarchies in the newly liberated countries..$^{35}$

Fraser was following established commonwealth behaviour in not publicly criticizing British policies. He alluded to an earlier discussion he had with Anthony Eden in May (undoubtedly when he attended the Prime Ministers' Conference in London) when he said that supporting the reestablishment of unpopular European monarchies in new liberated countries was 'a mistake of the first magnitude'. The form of postwar government, he said (and highlighted Greece), should be decided through elections. The New Zealand Prime Minister's words indicate that New Zealand policy toward Greece had apparently germinated during 1944. Furthermore, Fraser specifically named only one of the parties in the Greek political scene - the king. EAM/ELAS, and possibly other armed political groups, are relegated to those who would 'impose their will by force of arms'. In arguing against the return of the king, New Zealand was showing some independence from official British policy. In this respect, it is in tune with the published communications 
in the extant literature which shows that the government avoided sending New Zealand troops to Greece. At the same time, it conflicts with the neutralist view expressed in the literature. Fraser had indicted that he was not supporting the king. His criticism of the monarch was more pointed than his criticism of the resistance groups and paramilitary forces: whereas he wanted to dispense with George II completely, he merely attacked the latter's means of attaining power. Having said all of this, what constitutes New Zealand policy seems either to be one-off statements at a conference or a written response in time of crisis. There is no indication of a lineage of New Zealand decisions or statements extending back to before 1944 .

Popular protest faded by late December, but as noted below, Fraser's administration, frustrated by Churchill's reply, sought further intelligence about Greece. In short, they no longer trusted the British imperial diplomatic communications.

\section{Churchill sends a message, and New Zealand pursues the Greek issue with John Mulgan}

Churchill responded to Fraser two days after the latter sent his telegram of protest. He did not answer the essential question about the monarchy (not even the possibility of a plebiscite was considered) but related developments around the issue of appointing a Regent. ${ }^{36}$ Churchill was pursuing the standard British diplomatic practice of 'consulting' with the Dominions and also demonstrating his single-minded and authoritarian attitude toward them. Decision-making was still in the hands of London. ${ }^{37}$ Obviously, Fraser's diplomatic protest did not cause any change in British policy and actions.

Frustrated that Churchill's answer did not address the issues raised, Wellington considered other options to gain intelligence about the situation in Greece. The surviving records concerning this next phase revolve around Wellington-based New Zealand diplomat J.V. Wilson and the Secretary of the Department of External Affairs, Alister McIntosh. Given Fraser's style of leadership, it is difficult to consider that he did not have a hand in the discussions, especially as General Bernard Freyberg was proposed by Wilson as a possible source of political intelligence on the Greek situation. Wilson asked McIntosh, whether Freyberg or members of his staff (Geoffrey Cox, one of his intelligence officers, was specifically named) should be contacted to see if they 'might have information on the Greek situation which would be of use to us?' He recognized that 'perhaps in view of General Freyberg's position as one of Field Marshal Alexander's [Alexander had been directing the British operation in Athens] officers, it might not be right to communicate with him on the subject'; but that 'I do not think we can neglect any sources of information which we may reasonably consider our own' ${ }^{38}$ Neither Freyberg nor Cox was contacted. The partnership between 
Fraser and Freyberg so evident in the New Zealand war history and the latter's assertiveness with his British superiors did not extend to obtaining political intelligence on British actions. Instead, Wellington went to John Mulgan. Wilson had first met Mulgan when he visited Oxford in the 1930s. Later, when Mulgan was part of the New Zealand delegation to the League of Nations, they established a bond: 'J.V. Wilson he warmed to because of his surviving Messines and Passchendale, quite apart from his being a brilliant classical scholar and a self-effacing, entertaining man'. ${ }^{39}$ Wilson, of External Affairs, worked through a draft letter to send to Mulgan. He passed it by McIntosh. On 19 January 1945, a letter was sent to Mulgan via 2NZEF Brigadier Bill Stevens in Egypt. Wilson's request to Mulgan for information on Greece was bundled with a covering letter from Alister McIntosh to Stevens. McIntosh wrote: 'We are anxious, if possible, to get some unofficial views on Greece, and Mulgan may, or may not, be able to supply us with a few comments'. McIntosh's vague wording about John Mulgan's military status: 'I understand he is trying to get a transfer to the New Zealand forces' - leave one wondering whether he was willing to transgress the line and ask a serving officer in another army. ${ }^{40}$ Mulgan sent Wilson two letters, less than a week before his death. He was still an officer in the British army. Wellington got more than some brief comments. Mulgan sent them an extensive report.

As the opening paragraph of this paper showed, twenty years after Mulgan wrote to Wilson, the latter was still cautious about sharing what he had with a biographer. ${ }^{41}$ As indicated earlier, O'Sullivan and McNeish both mention the Wilson communication. Wellington's request to John Mulgan and the report have never been analysed in the literature. That Wellington still wanted intelligence after ELAS was defeated in Athens and New Zealand popular protest evaporated might show some degree of genuine interest in Greek affairs. Fraser's administration had been willing to maintain commonwealth solidarity but it was motivated enough to pursue intelligence on an issue that had a significant number of New Zealanders protesting.

\section{Mulgan in Athens}

On the day that Wilson sent his letter from Wellington, Mulgan had already been in Athens for five days. His assignment was to oversee claims for compensation from Greeks who had assisted SOE during the occupation. Managing this process would bring Mulgan into contact with the repercussions of both the death of EKKA's Psarros and the much-discussed Don Stott affair. Stott, a New Zealander, had met with Greek collaborators and German functionaries during the occupation. Arguments ensued - and have continued ever since - about whether Stott was merely pursuing military intelligence or, as EAM/ELAS believed, he was brokering a separate 
agreement with the Germans that did not include them. ${ }^{42}$ Mulgan was not simply involved in the administrative winding down of SOE apparatus and compensation claims. While Britain had prevailed in Athens, there were acute political tensions that had not been resolved and Mulgan was a player in this politically-charged environment. British archive records suggest that Britain was seeking and/or maintaining long-term contacts amongst the Greeks Mulgan was dealing with. This could mean they were being targeted for future intelligence work. In addition, Mulgan was also an actor in a security issue that, thanks to his colleague, Julian Dolbey, eventually escalated all the way to Winston Churchill.

The widow of Psarros, the EKKA leader who had been killed by ELAS the previous year, submitted one of the claims Mulgan had to evaluate. Mulgan and his superior officer, Dolbey, disagreed as to whether or not the payment should be paid. Mulgan did not think it should be granted. The incorrect and fatal assessment Mulgan and other British Liaison officers made the previous year did not apparently lead him to support the wife of the dead Psarros. Again, reflecting the ongoing debates concerning Greece, in 2003 a Greek scholar used the disagreement between the two SOE officers to counter a long-held conspiracy theory amongst Greek partisan veterans concerning Psarros and EKKA. ${ }^{43}$ The theory was that EKKA had been a pawn of the British. The reasoning, made nearly 60 years after the event and using British archives, was that Mulgan and Doleby's disagreement showed that EKKA had not simply been a British stooge.

Mulgan's handling of a claim from another Greek, Spyros Kotsis, led to Kotsis addressing a nine page letter (written a few days after Mulgan's death) to the British Prime Minister. It was apparently never sent, but was analysed by SOE. ${ }^{44}$ The submission named Stott and asserted that he never gave Kostis access to radio sets and funds. Kostis also mentions Stott's Athens episode. Although Stott is only discussed in several paragraphs and the compensation case as a whole is full of death, imprisonment and accusations of betrayal to the enemy, the fact remains that Mulgan again had to contend with the political legacy of the wartime resistance. Kotsis wrote, 'Mr. Mulgan, the representative of the other country [that is, Britain] for which I worked with so much sacrifice, cannot reward me with such a bitter cup instead of a word of thanks'. He adds later that, unless he receives recompense, he will have to commit suicide..$^{45}$ O'Sullivan's discussion of Kotsis includes the dismissal of the claim. Kotsis, however, pursued his accusations against Stott in a book written 31 years after his confrontation with Mulgan. His statements concerning Stott's mission were aired at the time of publication and again during a Modern Greek Studies conference panel forum in 1978. The latter, at least, attracted some criticism of his 
claims about Stott. Mulgan's scepticism about Kotsis was followed decades later by similar attitudes by scholars of wartime Greek history. ${ }^{46}$

While events from the past were still reverberating in the incidents briefly described above, planning for the future shows a continuation of British interests. In a communication dated 21 February, Dolbey told Mulgan that the latter had to clarify some confusion in his reports from Athens concerning a 'White List' that was being compiled. The list was 'intended to cover all Greeks who may be usefully employed by British interests. Therefore, the fact that a man is at present in employment is no reason why he should not be recommended as suitable for employment by a British firm at a later date'. ${ }^{47}$ Given the type of work SOE operatives had been doing, it is conceivable that this list might have done more than just providing a labour force for a 'British firm', as Dolbey says. Certainly in the previous year when initial high-level planning (excluding Mulgan, who had not been assigned) had begun for the liquidation and compensation operation, commitment to those loyal to Britain was such 'that patriots who are in disfavour with the post-war government of their country are given full protection. If necessary, SOE would consider using payment from secret funds or evacuation to another country'. In the same report, SOE's clandestine nature meant that, in the case of some groups in Athens, they considered (there is no record of them doing this) 'Funds would have to be sent in secretly, which means without the knowledge of British authorities who will be in control of the area'. ${ }^{48}$

In response to SOE's need for security Mulgan and Dolbey also sought ways to stifle newspaper articles in the Greek press concerning British intelligence officer David Pawson. Pawson had been one of SOE's Greek experts prior to being captured in the Aegean in late 1943. The information at hand is somewhat fragmented, but its tone and the extent of the affair adds context to Mulgan's experiences in Athens. On 14 April, Dolbey wrote to Mulgan concerning stories in the Greek newspaper I Vradini. The exact content of the stories is not clear, but Dolbey thought that 'it is undoubtedly very dangerous for Pawson's personal safety and for SOE operations' security'. Hinting at the still-undefeated EAM/ELAS (only Athens had been cleared in the aftermath of the December fighting, the rest of the country was still largely in their hands), he added 'you are in the midst of one of the political crises which will no doubt succeed one another in Greece for the next month or so in preparation for a second show down'. ${ }^{49}$ From his base in Cairo, Dolbey's escalation of the affair travelled upward to London. There, the Foreign Office laid the matter before Churchill. They argued that, besides compromising the personal safety of Pawson, the articles aimed to threaten British credibility: 'The intention of the series seems to be to criticise British activities in Greece before the liberation'. Churchill approved 
the requested 'direct action' for the British military to occupy the paper's offices, shut down the presses and confiscate all copies of the paper. ${ }^{50}$

Mulgan's experiences in Athens show the currents he was swimming in. His work resolving claims for compensation - thankless and psychologically draining - was accompanied by unresolved and potentially explosive political issues. All this took place in a war-devastated land with a dislocated economy and a capital city that had just been a battlefield. Although the Varkiza agreement had been signed during Mulgan's time in Athens, it was evident that the parties would collide again. Conflict and terror would continue intermittently in Greece for years to come.

Mulgan returned from Athens to Cairo on 19 April. For some reason, the delivery of the January letter from Wilson, via Stevens, was not made until he returned (both were apparently on the same flight from Greece). ${ }^{51}$

\section{Mulgan in Cairo and the New Zealand government}

Mulgan sent his report for Wilson in a letter dated 22 April. He included a separate preliminary note stating that being 'an army officer I'm not officially free to write or express my views without censorship', but he did not think what he was going to write was contentious. He had also written a letter two days before confirming receipt of the Wilson correspondence and promising a forthcoming report. That report encompasses a range of topics concerning the situation in Greece. Its high level of analysis is perhaps reflective of Mulgan's own abilities as well as his feelings about the suffering of the Greek people. As he told Wilson in the first letter: 'This has always made me personally a little humble in judging them and a little sceptical of wholesale condemnation'. Mulgan also thought his response to Wilson may have been too late and the need no longer as great. ${ }^{52}$ This was only partially true, in the sense that Wilson had access to some of the New Zealand soldier's assessment since February. Mulgan's father had provided Wilson with extracts from letters sent by his son to his parents (John was apparently unaware of this). They were from letters dated from 5 December 1944 until 21 January 1945 - that is, from the time fighting broke out in Athens until the time when John Mulgan returned there on his compensation work. Alan Mulgan included a note to Wilson with the first consignment of extracts, sent on 30 January. He told the diplomat: 'They are for your perusal alone' and that 'I think you will agree that in the circumstances his sequence of comments should remain, as intended, for private consumption, though they may be useful for forming opinions'. ${ }^{53}$ Alan Mulgan sent a second extract a month later in late February. Wilson circulated all the material to Alister McIntosh and other staff in the administration. Peter Fraser does not appear in the archives trail. 
The extracts show John Mulgan was critical of British foreign policy: 'The British Government has been consistently wrong' and its 'policy is so tortuous and the issues so mixed up that I'd rather not be associated with it'. The Greek communists receive a particularly savage assessment: 'The communists, of course, are bloody. I've seen enough of them at close quarters now to have a thorough distrust of their methods'. They also, Mulgan wrote, happily promote 'the theory that suffering and starvation are useful for the revolutionary situation that they produce'. ${ }^{54}$

The extract from the most recently dated letter (21 January) given to Wilson shows a John Mulgan more focused on the problems of his compensation work and the plight of civilians. This is understandable as most of the fighting in Athens had subsided by this time. Despite what had happened and his continued criticism of the communists, Mulgan was not inclined to totally discount EAM/ELAS: 'The British on the other hand won't admit that there might be any good people in these left movements and I'm likely to get arrested for even suggesting such a thing. ${ }^{55}$

The information contained in the letters John Mulgan set to his family undoubtedly gave Wilson and his colleagues grounding in John Mulgan's views about Greece. Mulgan's response to the Wilson/McIntosh approach provided more details. Individual personalities are sketched in the briefing paper Mulgan sent Wilson (for example, EAM/ELAS leaders such as George Siantos and Aris Velouchiotis, Zervas of EDES and Churchill). Even the briefest asides contain evaluations that are politically provocative. They also carry the credibility of being written by a serving officer who had extensive experience in the field. One would also have to place the communication in the context of coming after the recent fighting in Athens and amongst the still-unresolved political issues.

Mulgan's criticism continued to be directed across the political spectrum. He felt that Britain was acting like an imperial power trying to control an independent country, while ELAS was using unscrupulous methods of intimidation and terror and was undemocratic to the extent of being 'the fascism of the Left'. ${ }^{56}$ Their military effort against the Axis enemy was negligible. Partly, Mulgan recognized, this was a deliberate strategy to conserve their forces until the day of liberation - and anticipated revolution. The leadership of the Greek communist movement lends itself to accusations that they manipulated a situation to foster discontent and revolution. Mulgan differentiates between those communists doing the fighting (ELAS partisan leader Aris Vekouchiotis is named) and those directing it - the latter 'stayed in the background but had all the power'. He is also somewhat cynical of the communist leadership who had avoided being directly involved in the bloodshed. Hence, Siantos and Pantselides 'were circulating happily in 
Athens', while Karageorgos was reporting on the United Nations conference in San Francisco. ${ }^{57}$

The political dynamics of wartime Greece show a more complex vista than that of polarized communists versus supporters of the British-backed monarchy and government in exile. Support for the respective sides varied, but Mulgan notes: 'Up till the time of civil war [that is, probably the 'First Round' that started in October 1943] a voting majority of Greece would have been Venizelist left-wing liberals. Most of the men that I met and worked with in ELAS were of this kind, and I think they represented a general and predominant part of the country ${ }^{58}$ Reflecting on the continual wartime symbiosis between the forces within and external to Greece, Mulgan also states that the mutinies of the Greek armed forces in the Middle East were organized by former Greek operatives employed by the British to make contact with resistance groups. They were 'now imprisoned in the Sudan.' ${ }^{59}$ The statement, again, could have been a source of embarrassment to the British if it were ever made public.

Mulgan's assessment of Napoleon Zervas, the head of EDES and Britain's ally in the resistance movement, is worth analysing in some detail. Mulgan was possibly in a position to know more about the state of the partisan leader's personal finances than most. Zervas, according to Mulgan, 'has not been impoverished by the war'. Although 'It was a mistake nevertheless to lean heavily upon him or build him up as the leader of a non-communist resistance movement', he was 'a good natural guerilla leader and the type of cheerful scoundrel that it pays to employ in war-time.' Mulgan, although criticizing British foreign policy, still had a balanced opinion of Zervas.

However, his knowledge of the British ally's personal financial situation at a time when the whole country was in economic ruin requires exploration. A little more than three months before Mulgan wrote his letter to Wilson, Tom Barnes, a New Zealand officer on special service with SOE and attached to EDES, had bitterly observed in an official report (by its circulation list not apparently given directly to Wellington, but a copy sits in the New Zealand archives) that Zervas was having difficulty in meeting debts. EDES creditors 'were a common and unwelcome sight'. ${ }^{60}$ His partisans 'were in a sorry plight. They had received no clothes for months and were in rags . . . they received barely sufficient food to live on - this did not include olive oil, soap etc. without which they cannot live. They received no money in order to buy such necessities'. ${ }^{61}$ The usefulness of EDES was now at an end and, as such, they were being treated cynically by the British, who had cut off their financial support. They had been formally disbanded on 16 February. SOE often argued that Napoleon Zervas was a soldier of fortune with little or no ostensible political convictions during the war. However, Zervas did indeed enter politics in 1945 and became a Minister in a postwar government 
that fought the communists (by then termed 'bandits' by their Greek and British opponents). More than four years after EDES had been disbanded, its apparent (the British never seemed to verify the correspondent's bona fides) wartime Director General of the Financial Services wrote to the British Embassy of Greece and also to the House of Commons, ${ }^{62}$ refuting claims by a British MP that Zervas was 'an "adventurer" [and] cost Britain $30,000,000$ gold sovereigns', arguing that the amount was an 'incredible sum' in the context of the financial breakdown he provided. ${ }^{63}$ The extent of Zervas' pecuniary motivations while working with the British was still a sensitive issue. Mulgan's comment about Zervas not ending the war as a poor man would have undoubtedly added credibility at least to accusations of profiteering. Given the situation in Greece, any disclosure like this would have led to public outcry and embarrassment for Britain. It would stir the embers of open revolt.

Probably the most provocative statement made by Mulgan, a still-serving British officer, concerned hypothetical political choices he would make. He dismisses the rightists who were then forming a succession of Greek governments. The only viable alternative, he argued, was the communists. He wrote:

The Communist party in Greece has a good future, with or without Russian support, because it has a good organisation and discipline and knows where it is going. If I were a young man in Greece now, I would be tempted to join it with the idea of trying to ameliorate it from within. Its top men are good but the middle men, the local commissars and village thugs, are the worst type and need liquidating if anyone does in the brave new world. One would be tempted to join it, not with any love for it or belief in its doctrine but mainly from despair with its antithesis on the right and thinking cynically that the party would be likely to come to power sooner or later and that it would be as well to get on good terms with it now.

Given the sensitivity of the Pawson case mentioned previously, one could imagine the reaction such a view would elicit if made public. It is also telling that Mulgan, when considering joining the communists, entertained using the same methods he himself loathed about them - that is, liquidation. The ends for him justified the means. The statement also lies in stark contrast to his general sense of humanity, expressed in his sympathies toward the Greek people. Both of these elements have figured highly in the published record.

What Wilson and the Wellington administration thought of Mulgan's letter has not been located in the primary sources. However, one New Zealander used it, amongst other information, to argue John Mulgan had been killed 
in Cairo rather than having committed suicide. This was John Mulgan's father, Alan.

\section{Possibility of assassination is raised by Alan Mulgan}

Mulgan wrote his report for Wilson and Wellington just a few days before being found dead in his hotel room in Cairo. Disbelief and frustration ensued among his family in New Zealand and England (where his uncle lived). Mulgan's position as a serving officer with the British forces and the fact that SOE were in the midst of dismantling their administrative structures in Cairo exacerbated the family's difficulty in obtaining information. The family also sought information through unofficial channels. Given the nature of his work and the content of the letters Mulgan had written to both his parents and Wilson, it is not surprising that the possibility of assassination was raised. The trials of the Mulgan family in gaining specifics of their son's death and the extended investigation (the first investigation could not come to a unanimous conclusion and so a second was initiated) has been discussed in biographies of Mulgan. Mulgan's commanding officer rejected the possibility of suicide at the first enquiry and this has been interpreted as an accession to Mulgan's note asking him to try and conceal the suicide. ${ }^{64}$ The possibility of assassination has been obliquely mentioned by O'Sullivan: 'there were rumours, especially in Greek circles, of sinister undercover possibilities'. ${ }^{65}$

Alan Mulgan first raised the question of assassination in a letter to Peter Fraser on 21 August 1945. Alan Mulgan was a well known and respected author and journalist. Between 1935 and 1946, he was responsible for radio talks on the New Zealand Broadcasting Service. He was also an anglophile - his entry in the Oxford Companion to New Zealand Literature attributes him with 'late-Victorian moral conservatism, Empire loyalty and a sense of England as 'home'. ${ }^{66}$ As the January letter from Wilson-McIntosh to John Mulgan indicated, Alan was known personally to Wilson the diplomat. With his position, connections and literary standing, it could be argued that he was not just a member of the general public but of the establishment elite. ${ }^{67}$

During the remainder of the year, Alan Mulgan pursued the assassination theme in several letters to Alister McIntosh, Fraser's Secretary of the Department of External Affairs. He asked Fraser himself why the enquiries in Cairo still continued. A delay in the findings made him propose that there was some doubt about the actual cause. More pointedly, he speculated that John Mulgan had fallen victim to political violence: 'There is ample reason to suppose, however, that to many individuals and political factions, John was a dangerous man, and Greek politics are notorious for intolerance and vindictiveness'. The manuscript of John Mulgan's Report on Experience was also mentioned, as was the report to J.V. Wilson. Alan Mulgan knew not 
only of the report but also of its contents. He argued: 'As you will agree, this confidential report was highly dangerous if seen or known of by any of those he wrote of so frankly and critically'. There was also the possibility that the Greeks had John Mulgan under surveillance. Mulgan senior wanted Fraser's help in making this political perspective and the existence of the mentioned documents known to the authorities (both British Army and Egyptian civil ones) in Cairo. He also raised the possibility that a particular decision concerning his son's death might have been deliberately reached to 'avoid adding to international complications at such a time'. He specifically considers that Greek partisans would have wanted to avoid publication of his son's manuscript and that 'some of the Greeks may have found this out and been watching him'. It is not surprising that Alan Mulgan, a well know Anglophile, would speculate that the Greeks had dispensed with his son rather than the British (of whom John had been also been critical). He suggested that it was 'Greeks', rather than a specific group (such as ELAS partisans) or individual (such as Zervas or any of the communists), who may have killed his son. Unlike John, Alan Mulgan was imprecise (possibly deliberately) in his communication concerning Greek politics.

Alan Mulgan's fears might be seen in part as the natural reaction of a grieving father who refused to believe his son would commit suicide - such a proposition he wrote was 'quite fantastic'. He did, however, support his assertion with a quote from a letter written by SOE colleague Tom Barnes to John Mulgan's wife about how well Mulgan had looked the day before his death. ${ }^{6}$ If Alan Mulgan had been aware at the time that, on 30 April, the New Zealand Maadi Camp in Cairo had told the HQ of the 2NZEF that John Mulgan's 'Cause of death [is] not yet known but foul play is suspected' ${ }^{69}$ he would undoubtedly have questioned the suicide finding even more forcefully. Alan Mulgan pursued the possibility of assassination in another letter on 4 September, written to McIntosh. Again, he dismissed the idea of suicide, and stressed his son's character, including a letter from Geoff Cox, a friend of John Mulgan and the intelligence officer that Wilson thought earlier they might contact instead of Mulgan. He pressed for Wellington to question other figures who might be able to provide additional information. One was a Greek who had typed part of the Report on Experience manuscript. He quoted a letter from his son: 'an odd little Greek typed the first part'. Alan Mulgan thought: 'This is the sort of evidence that would probably not be known to the authorities in Cairo'. Another possible source of information was an officer from Dunedin who had worked with John Mulgan during the relief operations to newly liberated Greece. Finally, there was a British officer with the British Embassy in Greece. Alan Mulgan suggested avenues to pursue but left the Wellington government to decide (or act). He then moved to a more specific claim - that it might be the Egyptians who 
wanted to cover up a politically motivated crime..$^{70}$ The final letter was written on 2 December. Having received, at McIntosh's request, the final official report on his son's death from General Bill Stevens, Alan Mulgan raised the possible political motives as well as 'John's domestic affairs' (undoubtedly referring to his romantic affairs which were included in the initial investigation and named as the reason for suicide). Regarding the former, he included information he had obtained from Tom Barnes, that Communists had murdered several people in Cairo and reiterated that it was apparently not known in Cairo that John had written on political conditions in Greece'. ${ }^{71}$ Alan Mulgan was both introducing his son's personal life as well as being more specific about which Greeks might have killed his son. His earlier singular view about the political dimension had been diluted, but at the same time, he had made his allegation more precise by specifically naming Greek communists as the perpetrators.

Records show that Fraser's government pursued information on the process and outcomes of investigations into Mulgan's death, ${ }^{72}$ and Fraser told General Bernard Freyberg to verify that the investigation and proceedings ${ }^{73}$ were all in order. But there is no indication that the government ever passed on to the investigating authorities any information about the political writings of John Mulgan - either in the form of letters to his family or the report he sent to Wilson.

The subsequent scholarly work on Mulgan and my own research using British and New Zealand archives make the official verdict of suicide seem more plausible than the argument for political assassination. The intimacy of the suicide note John Mulgan left his commanding officer, including the use of the term 'liquidation' to describe his own demise - a word which they had often used in their compensation work - is something an assassin could not duplicate. There were no signs of any struggle or any evidence of a forced external entry into his room or visitors. That a grieving family should think John Mulgan had been dispatched for political reasons is unsurprising. His report to Wilson, family correspondence and the explosive experiences of December 1944 would all contribute to such a view. Whether or not the investigation and official finding of suicide would have been influenced by the information Alan Mulgan wanted the Wellington government to forward to Egypt is pure conjecture. Much more certain is that the Fraser government avoided political embarrassment by not informing the investigating British of their unofficial correspondence with John Mulgan.

\section{Conclusion}

John Mulgan was engaged in politically charged activities in relation to wartime Greece. His pre-war connection with the Wellington administration and their recognition of his analytical abilities led them to seek out 
his analysis of newly liberated Greece. The actions of Peter Fraser's government to obtain intelligence independent of the standard commonwealth apparatus - in response to domestic pressure - show the accepted view in the literature of implicit New Zealand neutrality is somewhat erroneous. The New Zealand administration's reluctance to pursue requests to send Mulgan's communications to the investigating authorities in Egypt, however, demonstrates the limits to which it was prepared to engage in action independent of London.

\section{Abbreviations}

ATL - Alexander Turnbull Library

ANZ - Archives New Zealand/Te Rua Mahara o te Kāwanatanga, Wellington Office

NZDFA - New Zealand Defence Force Archives, Trentham

PRO - Public Records Office, Kew

1 I would like to thank Professor Richard Mulgan for granting me access to the Mulgan family papers. Also, Professor Vincent O'Sullivan for his continued encouragement of my exploration of the political dimension of the New Zealanders who served with SOE in Greece. Prof O'Sullivan has also made available at the Alexander Turnbull Library British archival material gathered in his own research. Associate Professor Vrasidas Karalis and Dr Anthony Dracopoulos of University of Sydney guided me through a postgraduate thesis, part of which provided the basis of this paper. My sincere thanks to Dr Ray Goldstein for his constructive criticism and Richard Drummond for his proof reading. The Ministry of Foreign Affairs and Trade provided funding which contributed toward research. Finally the Stout Research Centre for appointing me as an Adjunct Research Associate 2008-09 and providing the opportunity to present my research in public seminars.

2 J.V. Wilson to Paul Day, 27 March 1965, J.V. Wilson Papers, MS papers 6875-3, Alexander Turnbull Library (ATL).

3 John Mulgan to J.V. Wilson, 22 April 1945. J.V. Wilson Papers, MS Papers-6875-2, (ATL).

4 Paul Day to J.V. Wilson, 30 March 1965, J.V. Wilson Papers. The earlier request to copy the documents was made on 22 March. Paul Day to J.V. Wilson, 22 March 1965, J.V. Wilson Papers, MS Papers-6875-3 (ATL).

5 M.R.D. Foot in the foreword to the recent edition of Report on Experience. John Mulgan, Report on Experience, Barnsley, 2010, p.12.

6 Marina Petrakis, Metaxas Myth: Dictatorship and Propaganda in Greece, London, 2006, pp.34-37.

7 Andre Gerolymatos, Red Acropolis, Black Terror: Greek Civil War and the Origins of Soviet-American Rivalry, 1943-1949, New York, 2004, p.29.

8 Procopis Papastratis, British Policy Towards Greece During the Second World War 1941-1944, London, 1984, pp.2-3.

9 Richard Clogg, Anglo-Greek Attitudes: Studies in History, New York, 2000, p.153. For a summary of British policy toward King George and his government see ch.7.

10 OSS L-46149 National Archives and Records Administration (NARA), Washington D.C. Cited in Evangelos Spyropoulos, Greek Military (1909-1941) and the Greek Mutinies in 


\section{John Mulgan's Greek Wartime Life and Death}

the Middle East (1941-1944), New York, 1993. The author also quotes from the diary of the Greek Premier Emmanuel Tsouderos.

11 C.M. Woodhouse, Something Ventured, London, 1982, p.29.

12 The citations mentioned in this section come from the earlier edition of Mulgan's work. The 2010 version includes items originally omitted. Given the changes indicated by the editor, they do not have a bearing on the sections to do with Greece. John Mulgan, Report on Experience, Barnsley, 2010.

13 Mark Mazower, Inside Hitler's Greece: the Experience of Occupation, New Haven, 1993, p.304.

14 M.R.D. Foot, SOE: an Outline History of the Special Operations Executive 1940-46, London, 1984, p.236.

15 Clogg, Anglo-Greek Attitudes, pp.115, 135.

16 Nicholas Hammond, Venture into Greece: With the Guerillas 1943-1944, London, 1983, p.141.

17 Stefanos Sarafis, ELAS: Greek Resistance Army, New Jersey, 1946, pp.292-3.

18 Argyrios Mamarelis, 'The Special Operations Executive in Greece 1941-1944: The case of the 5/42 Regiment of Evzones', 1st LSE PhD Symposium on Modern Greece, LSE, 21 June 2003, p.6.

19 Ibid. pp.14-16

20 Dean Parker, Greek Fire, Wellington, 2008.

21 Paul Day, John Mulgan, London, 1977, sections 6-7; Vincent O’Sullivan, Long Journey to the Border: A Life of John Mulgan, Auckland, 2003.

22 O'Sullivan, p.335.

23 James McNeish, Dance of the Peacocks: New Zealanders in Exile in the Time of Hitler and Mao Tse-tung, Auckland, 2003, p.260.

24 F.L.W. Wood, Political and External Affairs, Wellington, 1958, p.365

25 New Zealand Herald (NZH), 5 December 1944.

26 NZH, 12 December 1944.

27 The Times, 15 January 1945.

28 C.M. Woodhouse, Modern Greece: a Short History, London, 1998, p.245.

29 Ibid., pp.254, 256.

30 EA1 201/2/82 Part 2B 22433 (ANZ).

31 Press (PR), 9 and 11 December 1944; NZH, 14 December 1944.

32 PR, 15 December 1944.

33 NZH, 15 December 1944.

34 Office of High Commissioner, Wellington, to Alister McIntosh, 16 December 1944. EA1 201/2/82 Part 2B 22433 [ANZ]. The British representative pointed out that 'Actually, as you will have observed, this has all been reported verbatim in the New Zealand press.'

35 Fraser to Secretary of State for Dominion Affairs, 20 December 1944. EA1 201/2/82 Pt 2 B 22433 (ANZ).

36 Archbishop Damaskinos became regent. Churchill's initial suspicions of him being an EAM/ELAS supporter faded and he supported the appointment. Winston Churchill, Second World War Volume VI: Triumph and Tragedy, London, 2005, pp.268-73, 276.

37 Churchill to Fraser, EA1 201/2/82 Pt 2B 1940-1944 (ANZ).

38 Memorandum Wilson to McIntosh. A draft request wording to Freyberg was included by Wilson. EA 1 Box 118 201/2/82 Greece part 2 (ANZ). 


\section{Journal of New Zealand Studies}

39 O’Sullivan, p.167

40 Alister McIntosh to Bill Stevens, 19 January 1945, McIntosh Papers, MS Papers 6759350, (ATL).

41 J.V. Wilson to Paul Day, 27 March 1965, Day's reply 30 March 1965, J.V. Wilson Papers, MS papers 6875-3 (ATL).

42 Clogg provides a recent analysis: Richard Clogg, 'Negotiations of a Complicated Manner: Don Stott's adventures in Athens, October-November 1943', in Mark Seaman, ed., Special Operations Executive: a New Instrument of War, New York, 2006, pp.148-56.

43 Mamarelis, p.8.

44 O'Sullivan, p.329. O'Sullivan includes the episode in his biography, but the link to Don Stott is not explored.

45 Spiros Kotsis to Winston Churchill, 30 April 1945. HS 5/341 (PRO). A copy of the document is in O'Sullivan Papers, MS Papers-8612-90 (ATL).

46 Marion Sarafis, ed., Greece, from Resistance to Civil War, Nottingham, 1980, pp.103-7.

47 Dolbey to Mulgan, 21 February 1945. Dobrski Papers, Liddell Hart Centre for Military Archives (LHCMA), London. A copy is in the O'Sullivan Papers, MS Papers-8612-095 (ATL).

48 Summary of Directives Received from SOM with Reference to Liquidation of SOE Organisations, 15 August 1944. HS 5/514 (PRO). A copy is in the O'Sullivan Papers, MS Papers-8612-090 (ATL).

49 Dolbey to Mulgan, 14 April 1945. Dobrski Papers, (LHCMA). A copy is in the O'Sullivan Papers, MS Papers-8612-095 (ATL).

50 Minute 25 April 1945, FO 954/24 (PRO).

51 Mulgan to Wilson, 20 April 1945. Mulgan makes the point about delay in this. J.V. Wilson Papers, MS Papers-6875-2 (ATL). Brigadier Mitchell of the 2NZEF wrote an officer in Wellington that both Stevens and Mulgan flew to Cairo from Greece on 19 April 1945. Extract from Brigadier J.M. Mitchell, Maadi Camp, July [indecipherable day] 1945. McIntosh Papers, MS Papers-6759-044 (ATL).

52 Mulgan to Wilson, 20 April 1945 and Mulgan to Wilson 22 April 1945. J.V. Wilson Papers, MS Papers-6875-2 (ATL).

53 AAEG 950 box 137a 201/4/82 pt 322434 (ANZ).

54 Ibid.

55 Ibid.

56 John Mulgan to J.V. Wilson, 22 April 1945, J.V. Wilson Papers, MS Papers-6875-2 (ATL). The quote, and subsequent quotes, are from Mulgan's report to Wilson, 22 April 1945.

57 George Siantos was acting Secretary General of the Greek Communist Party during the wartime occupation. Dimitros Partsalides was a member of the central committee of EAM. Kostas Karageorgos was a journalist and EAM representative. Any unity in EAM/ELAS and even within the KKE would fracture following the events of December and the Varkiza Agreement. Aris broke with the KKE and fled to the countryside where he was killed by government security forces. Many EAM political affiliations broke away.

58 John Mulgan to J.V. Wilson, 22 April 1945, J.V. Wilson Papers, MS Papers-6875-2 (ATL).

59 Ibid. 


\section{John Mulgan's Greek Wartime Life and Death}

60 C.E. Barnes, Observations in Greece. Report on Observations in Greece: 1 October 1942 27 February 1945, p.43. WAII 1 DA 491.2/12 (ANZ).

61 Ibid., p.42.

62 A. Petassis to President House of Commons, 12 November 1949, FO 371/78419 Public Records Office (PRO).

63 A. Petassis to British Embassy, Athens, 7 November 1949. FO 371/78419 (PRO).

64 Day, 1977, pp.51-3.

65 O’Sullivan, Postscript.

66 Roger Robinson and Nelson Wattie, eds, Oxford Companion to New Zealand Literature, Oxford, 1998, p.385.

67 J.V. Wilson to John Mulgan, 15 January 1945, McIntosh Papers, MS Papers-6759-350, (ATL).

68 Alan Mulgan to Peter Fraser, 21 August 1945, McIntosh Papers MS Papers-6759-044, (ATL).

69 HQ NZ Maadi Camp to HQ 2 NZEF, 30 April 1945, PF 91369 John Mulgan (NZDFA).

70 Alan Mulgan to Alister McIntosh, 4 September 1945, McIntosh Papers, MS Papers-6759-044, (ATL).

71 Alan Mulgan to Alister McIntosh, 2 December 1945, McIntosh Papers, MS Papers-6759-044, (ATL).

72 Stevens to McIntosh, 21 September 1945. McIntosh MS Papers-8612-091 (ATL). Apparently McIntosh wrote Stevens six days after Alan Mulgan wrote his letter to Fraser.

73 O'Sullivan, Postscript. O'Sullivan points out that Freyberg dispatched Thaddeus McCarthy, then a barrister serving with 2 NZEF and a future New Zealand Supreme Court judge. 
Journal of New Zealand Studies 